\title{
Nurses in the labor market: professional insertion, competencies and skills
}

\author{
O enfermeiro no mercado de trabalho: inserção, competências e habilidades \\ El enfermero en el mercado de trabajo: inserción, competencias y habilidades
}

\section{Vilanice Alves de Araújo Püschel', Dafeni Costa", Priscila Patrício Reis", Larissa Bertacchini de Oliveira', Fábio da Costa Carbogim'}

\author{
'Universidade de São Paulo, School of Nursing, Postgraduate Program in Nursing. São Paulo, Brazil. \\ "Universidade de São Paulo, School of Nursing, Undergraduate Program in Nursing. São Paulo, Brazil.
}

How to cite this article:

Püschel VAA, Costa D, Reis PP, Oliveira LB, Carbogim FC. Nurses in the labor market: professional insertion, competencies and skills. Rev Bras Enferm [Internet]. 2017;70(6):1220-6. DOI: http://dx.doi.org/10.1590/0034-7167-2016-0061

Submission: 11-17-2016

Approval: 01-18-2017

\section{ABSTRACT}

Objective: to characterize nurses graduated from the School of Nursing of the University of São Paulo, from 2006 to 2012; verify their entry, facilitating factors and difficulties of these graduates in the labor market and to consider their skills and competences in the world of work. Method: an exploratory, descriptive study with a qualitative approach. Results: out of 505 graduates, 172 (34.1\%) participated in the research. Entry into the labor market was mainly via public hospital institutions, in the SE of Brazil, in the caregiving sectors. The greater part remained from one to two years in their first job. Most agreed that they were prepared to meet the health needs of the population. Furthermore, they had been encouraged to seek systematic and continuous improvement in a critical, reflexive and creative way, while combining technical-scientific knowledge and personal skills. Conclusion: the results show that the University of São Paulo has been preparing nurses for work in the labor market, in accordance with the provisions of the National Curricular Guidelines.

Descriptors: Nursing; Nursing Students; Labor Market; Employment; Human Resources.

\section{RESUMO}

Objetivo: caracterizar enfermeiros egressos da Escola de Enfermagem da Universidade de São Paulo (EEUSP), período de 2006 a 2012; verificar a inserção, as facilidades e dificuldades desses egressos no mercado de trabalho e apreender suas habilidades e competências no mundo do trabalho. Método: estudo exploratório, descritivo, de natureza quantitativa. Resultados: dos 505 egressos, 172 (34,1\%) participaram da pesquisa. A inserção no mercado de trabalho se deu majoritariamente em instituições hospitalares públicas, na região Sudeste, na área da assistência. A maior parte permaneceu nos primeiros empregos de um a dois anos. A maioria concordou que foi preparada para o atendimento às necessidades de saúde da população, que foi estimulada a buscar aperfeiçoamento sistemático e contínuo, de forma crítica, reflexiva e criativa, aliando conhecimento técnico-científico e habilidades pessoais. Conclusão: os resultados evidenciam que a EEUSP vem preparando enfermeiros para atuar no mundo do trabalho, conforme preceitos das Diretrizes Curriculares Nacionais.

Descritores: Enfermagem; Estudantes de Enfermagem; Mercado de Trabalho; Emprego; Recursos Humanos.

\section{RESUMEN}

Objetivo: caracterizar enfermeros egresos de la Escuela de Enfermería de la Universidade de São Paulo (EEUSP), período de 2006 a 2012; verificar la inserción, a las facilidades y dificultades de esos egresos en el mercado de trabajo y asimilar sus habilidades y competencias en el mundo del trabajo. Método: estudio exploratorio, descriptivo, de naturaleza cuantitativa. Resultados: de los 505 egresos, $172(34,1 \%)$ participaron de la pesquisa. La inserción en el mercado de trabajo se dio mayoritariamente en instituciones hospitalarias públicas, en la región Sureste, en el área de asistencia. La mayor parte permaneció en los primeros empleos de uno a dos años. La mayoría concordó que fue preparada para el atendimiento a las necesidades de salud de la población, que fue estimulada a buscar perfeccionamiento sistemático y continuo, de forma crítica, reflexiva y creativa, aliando conocimiento técnico-científico y habilidades personales. Conclusión: los resultados evidencian que EEUSP viene preparando enfermeros para actuar en el mundo del trabajo, según preceptos de las Directrices Curriculares Nacionales.

Descriptores: Enfermería; Estudiantes de Enfermería; Mercado de Trabajo; Empleo; Recursos Humanos. 


\section{INTRODUCTION}

The profound global transformations resulting from scientific, economic and technological development have brought about important changes in habits, values, priorities and in the vision of oneself, others and the world ${ }^{(1-2)}$. This has required new rules for social coexistence, new professional practices and new education permeated by continuous updating, as well as a refusal to simplify and fragment knowledge $\mathrm{e}^{(1,3)}$. In this context, intellectual characteristics and requirements are needed for future professionals: initiative, autonomy, problem-solving ability, creativity, computer skills and foreign languages ${ }^{(4)}$.

The technology accumulated, as a consequence of scientific development, has a broad permeability into the contemporary world. In health care, it is no different, however, the care of humans requires much more than techniques and technology; it requires listening, sensitivity and zeal. This aspect has provoked discussions in the area, which has resulted in much thought and proposals for changes in health education policies, pressing for transformations in accordance with the health needs of the population ${ }^{(1,3)}$. These changes stem from elements such as: new models for organizing the world of health work and requirements in the profile of new professionals focused on integrality and transdisciplinarity, in order to effectively impact health indicators ${ }^{(1,3,5)}$.

Thus, there is a need to introduce changes in the training of professionals, which requires the construction of new Political-pedagogical Projects that prepare professionals to deal with the challenges of professional practice in a world undergoing constant transformation ${ }^{(5)}$.

Brazilian higher education, based on the Lei de Diretrizes e Bases da Educação (LDB) [Law on Guidelines and Bases of Education], was called to restructure its philosophical, political, methodological and conceptual principles, guided by pedagogical projects that ensure education is linked to the world of work and reality of social practices, allowing the development of skills and competences as a multidisciplinary, cultural, scientific and technical production ${ }^{(6)}$.

Accordingly, following the guidelines of the $\operatorname{LDB}^{(6)}$, the National Curricular Guidelines for the Nursing Undergraduate Course $(\mathrm{NUC})^{(7)}$ were approved. These Guidelines, in addition to establishing a commitment to the training of nurses for the Unified Health System (SUS), have established an expanded knowledge, with an integral, generalist, critical-reflective, humanistic approach based on scientific, intellectual rigor and ethical principles ${ }^{(7)}$.

Researchers ${ }^{(1,3,5,8-9)}$ have revealed concern regarding teaching nursing in studies expressing, in synthesis, the relationships between educational practice developed in colleges and the reality of preparing nurses to perform their role in health services.

In the midst of these processes of change, the current Pedagogical Political Project (PPP) of the Nursing undergraduate course at the School of Nursing, University of São Paulo was restructured and its implementation took place in 2010. The course lasts four years, amounting to 4,170 hours study, distributed in an eight-semester full-time program ${ }^{(10)}$.

The central axis of the curriculum is Nursing Care, in its various meanings, significance and dimensions. The curricular organization is structured in modules that explain the articulations of the multitude of knowledge, made up of sets of disciplines or individual disciplines, in order to define the knowhow essential for the initial training of generalist nurses ${ }^{(10)}$.

It is of great importance to continue the study on USP graduates from 2000 to $2005^{(4)}$, the institution's emphasis on training nurses, the reformulation of its PPP and the 15 years of publication of the NUCs ${ }^{(7)}$ for the Nursing Courses. Consequently, it is relevant to conduct investigations that seek to understand the training process, its changes and impact; from the perspective of the graduates who graduated in the prior curriculum of USP. Such knowledge would provide insights for future research with graduates of the new curriculum, in order to assess their profile and the influence of the previous and current curricula on their insertion in the labor market and professional practice based on the precepts of the $\mathrm{NUCs}^{(7)}$.

Thus, this study had the following objectives: Characterize nurses that graduated from USP, from 2006 to 2012; Verify the professional insertion, facilitating factors and difficulties of these graduates in the labor market; and consider their skills and competencies in the work scenario.

\section{METHOD}

\section{Ethical aspects}

The project was approved by the Research Ethics Committee of USP. The participants agreed to sign the Free and Informed Consent Form.

\section{Study design, location and period}

An exploratory, descriptive study with a quantitative approach was performed. The e-mails and research instrument were sent by the USP administration to graduates who had graduated there from 2006 to 2012.

\section{Sample, inclusion and exclusion criteria}

A total of 505 individuals were identified who had graduated from USP between 2006 and 2012. These were sent the data collection instruments via the email registered in the institution's Graduate Service. Those who did not answer the questions in full were excluded.

\section{Study protocol}

For data collection, an instrument was used to characterize graduates (age, sex, marital status, religion, foreign language skills, year and duration of undergraduate nursing course, as well as any form of postgraduate course, time taken to enter the job market, where they are working or have worked, how the jobs were obtained, the length of time in these jobs, positions and functions, and employment type at the time of data collection) and also questions about the facilitating factors and difficulties experienced in obtaining a job in the labor market.

The second instrument contained questions that considered the skills and abilities acquired by the graduates of USP, according to the precepts of the NUCs ${ }^{(7)}$. This instrument was constructed in the form of a five-point Likert scale, where score 1 refers to "strongly disagree" and 5 "strongly agree". 
The instruments were sent to the e-mail addresses of all 505 nurses who graduated in the period from 2006 to 2012, according to the register obtained from the USP Graduate Service. Great difficulty was encountered in locating these individuals, due to outdated e-mails. These were eventually contacted by searching social networking sites and by requesting their contact details from colleagues who responded to the survey.

\section{Data analysis}

Data analysis was performed according to the absolute frequency and relative frequency of responses to the research instruments.

\section{RESULTS}

\section{Characterization of the graduates}

A total of 172 graduates completed the instrument in its entirety, $34.1 \%$ of these graduated from the USP in the period analyzed, of which $20.4 \%$ completed the course in $2010 ; 16.9 \%$ in 2012; and $62.8 \%$ between 2006 and 2011. The majority were female $(92.4 \%)$, single $(67.4 \%)$ and Catholic (46\%). The mean age was 29 years; they resided predominantly in the Southeast region of Brazil (95.8\%) and had no children (91.8\%).

Regarding course duration, 152 graduates (88\%) completed the course in four years; 16 graduates $(9 \%)$ in five years; and in six years, only four graduates $(2 \%)$. During the undergraduate program, 127 graduates $(73.8 \%)$ did not engage in any paid activity, $44(25.6 \%)$ did some paid activity, such as extracurricular paid internship, nursing technician, USP monitor, teacher, waitress, salesperson, and one that declined to answer this question $(0.6 \%)$.

In terms of language skills, the participants reported that they had advanced (37\%), intermediate (41\%) and basic (22\%) knowledge of English; while for Spanish, 6\% advanced, $19 \%$ intermediate and $80 \%$ basic; French, 1\% advanced level and intermediate knowledge and $16 \%$ basic level. In addition, $10 \%$ of the participants mentioned having a basic knowledge of other languages, such as Japanese, Italian and Mandarin.

After graduation, there was a great demand for postgraduate courses, especially lato sensu, among $63.9 \%$ of graduates, as presented in Table 1.

Table 1 - Postgraduate courses taken by graduates from the School of Nursing, University of São Paulo from 2006 to 2012, São Paulo, Brazil, 2015

\begin{tabular}{lcc}
\hline \multirow{2}{*}{ Post-graduation } & \multicolumn{2}{c}{ Graduates } \\
& $\mathbf{n}$ & $\%$ \\
\hline Specialism/Residency & 129 & 63.7 \\
Masters & 49 & 24.3 \\
Doctorate & 11 & 5.5 \\
Other & 13 & 6.4 \\
Total & $202 *$ & 100.0 \\
\hline
\end{tabular}

Note: *the total is greater than the number of participants (172), since some graduates completed more than one course.

\section{Professional insertion into the labor market}

With regard to the time that USP graduates took to enter the labor market, $25.6 \%$ took less than three months; $27.3 \%$, from three to six months; $26.7 \%$, from six months to one year; and $11.6 \%$, one year or more. However, $8.7 \%$ reported not having worked as a nurse. Among the reasons: admission to the masters, residency or doctorate course at USP; completion of a second graduation; low wages; and quality of life incompatible with their expectations.

The graduates had greater insertion in hospital institutions in the first, second and third jobs $(56.7 \%, 43 \%, 48 \%$, respectively), as shown in Table 2.

Table 2 - Institutions responsible for hiring in the first, second and third jobs of graduates from the School of Nursing University of São Paulo, 2006 to 2012, São Paulo, Brazil, 2015

\begin{tabular}{lcccccc}
\hline \multirow{2}{*}{ Institution } & \multicolumn{2}{c}{ First job } & \multicolumn{2}{c}{ Second job } & \multicolumn{2}{c}{ Third job } \\
& $\mathbf{n}$ & $\mathbf{\%}$ & $\mathbf{n}$ & $\mathbf{\%}$ & $\mathbf{n}$ & $\%$ \\
\hline Hospital & 89 & 56.7 & 43 & 43.0 & 24 & 48.0 \\
UBS & 23 & 14.7 & 18 & 18.0 & 12 & 24.0 \\
Vocational training & 12 & 7.6 & 6 & 6.0 & 0 & 0.0 \\
Homecare & 8 & 5.1 & 0 & 0.0 & 0 & 0.0 \\
Higher education & 4 & 2.6 & 8 & 8.0 & 6 & 12.0 \\
Laboratory & 3 & 1.9 & 1 & 1.0 & 2 & 4.0 \\
CAP & 1 & 0.6 & 3 & 3.0 & 0 & 0.0 \\
Others & 17 & 10.8 & 21 & 21.0 & 6 & 12.0 \\
Total & 157 & 100.0 & 100 & 100.0 & 50 & 100.0 \\
\hline
\end{tabular}

Note: *Basic Health Unit; ** Psychosocial Care Center.

The main forms of getting the first three jobs was the selection process $(47.1 \%, 58 \%$ and $57 \%$, for jobs 1 to 3 , respectively); followed by public tender $(24.1 \%, 26 \%$ and $29 \%)$; and for the first job recommendation from colleagues (11.4\%).

Regarding the length of stay in the first, second and third jobs, in the first job the duration ranged from one to 90 months; in the second, from one month to 72 months; and in the third, from 12 days to 60 months. See Table 3.

Table 3 - Duration of first second and third jobs of graduates from the School of Nursing, University of São Paulo, 2000 to 2005, São Paulo, Brazil, 2015

\begin{tabular}{|c|c|c|c|c|c|c|}
\hline \multirow{2}{*}{ Duration } & \multicolumn{2}{|c|}{ First job } & \multicolumn{2}{|c|}{ Second job } & \multicolumn{2}{|c|}{ Third job } \\
\hline & $\mathbf{n}$ & $\%$ & $\mathbf{n}$ & $\%$ & $\mathbf{n}$ & $\%$ \\
\hline 1 to 6 months & 45 & 28.0 & 24 & 25.0 & 13 & 30.0 \\
\hline 7 to 12 months & 31 & 19.3 & 16 & 16.0 & 4 & 9.0 \\
\hline 13 to 18 months & 11 & 6.8 & 7 & 7.0 & 6 & 14.0 \\
\hline 19 to 24 months & 25 & 15.5 & 16 & 16.0 & 7 & 16.0 \\
\hline 25 to 30 months & 10 & 6.2 & 5 & 5.0 & 0 & 0.0 \\
\hline 31 to 36 months & 12 & 7.4 & 10 & 10.0 & 2 & 5.0 \\
\hline 37 months or more & 27 & 16.8 & 8 & 8.0 & 10 & 23.0 \\
\hline Did not answer & 0 & 0.0 & 11 & 11.0 & 2 & 5.0 \\
\hline Total & 161 & 100.00 & 97 & 100.0 & 44 & 100.0 \\
\hline
\end{tabular}


The majority of graduates $(29.9 \%, 60.4 \%$ and $51.0 \%)$ obtained a salary of at least US\$1,143.95 in their first three jobs (Table 4).

Table 4 - Monthly salary/income in US dollars in the first second and third jobs for graduates from the School of Nursing, University of São Paulo, 2006 to 2012, São Paulo, Brazil, 2015

\begin{tabular}{lccccccc}
\hline \multirow{2}{*}{$\begin{array}{l}\text { Monthly salary/ } \\
\text { income (US\$) }\end{array}$} & \multicolumn{2}{c}{ First job } & \multicolumn{2}{c}{ Second job } & \multicolumn{2}{c}{ Third job } \\
& n & \% & n & \% & n & \% \\
\hline 153.59 to 490.19 & 18 & 11.4 & 4 & 4.1 & 0 & 0.0 \\
490.35 to 816.99 & 32 & 20.3 & 12 & 12.5 & 8 & 16.3 \\
817.15 to 980.39 & 27 & 17.1 & 13 & 13.5 & 5 & 10.2 \\
980.55 to $1,143.79$ & 24 & 15.2 & 8 & 8.3 & 6 & 12.2 \\
$\geq 1,143.95$ & 47 & 29.9 & 58 & 60.4 & 25 & 51.0 \\
Did not answer & 9 & 5.7 & 1 & 1.0 & 5 & 10.2 \\
Total & 157 & 100.0 & 96 & 100.0 & 49 & 100.0 \\
\hline
\end{tabular}

With regard to the position or function of the graduates in their first, second and third jobs, it was found that most were assistant nurses $(87.2 \%, 82.7 \%$ and $80.0 \%$, respectively). The second most cited function was a university teaching post $(5.76 \%, 12.5 \%$ and $12.2 \%)$.

Regarding the employment situation of the graduates at the time of data collection, only $0.6 \%$ stated that they were not employed. The institutions employing the highest number of graduates were hospitals (50.3\%); followed by Basic Health Units (16.5\%) and the higher education and vocational training sector (12.7\%).

\section{Facilitating factors for entering the job market}

Among the facilitating factors cited by the graduates regarding entry into the job market, the following stand out: graduation from the University of São Paulo given the university's good reputation in the labor market (16.3\%); the theoretical-practical, technical and scientific knowledge acquired during graduation (14.5\%); the completion of specialization courses and multi-professional improvement (14.5\%); and extracurricular courses and placements during graduation (10.4\%). The main favorable personal characteristics cited were: initiative, interest, persistence and good preparation for selection processes $(5.2 \%)$; and performing well in these processes $(2.32 \%)$.

\section{Difficulties for entering the job market}

Of the difficulties mentioned for the entry of graduates in the labor market, the following stand out: problems related to training, personal characteristics and the unfavorable labor market itself.

Regarding their training, the difficulties were: requirement of postgraduate and or specialization in the area (41.4\%); fulltime course $(27.6 \%)$; lack of professional experience during graduation $(24.1 \%)$; having a completed postgraduate and or specialization course $(6.9 \%)$. Regarding difficulties related specifically to the labor market, they cited: lack of experience as they were recently graduated $(83.5 \%)$; decrease in employment opportunities and remuneration (10.1\%); lack of personal contacts or recommendations $(6.3 \%)$. With regard to personal characteristics: difficulties in the selection process
(40\%); working day (33.3\%); age (13.3\%); immaturity $(6.7 \%)$; and having children $(6.7 \%)$.

Skills and competences of graduates from the School of Nursing, University of São Paulo, in the workplace

Considering the Likert scale applied, the students answered the questions related to their competences and abilities according to the profile traced by the NUCs.

Regarding whether the course had been effective in terms of developing prevention, promotion, protection and rehabilitation health programs, 59 (34\%) students fully agreed, 106 $(62 \%)$ agreed, 6 (3\%) disagreed and none fully disagreed.

Among the general competencies described in the NUCs, graduates were asked if the course had prepared them to take leadership positions: forty-one (24\%) respondents fully agreed, 95 (55\%) agreed, 31 (18\%) disagreed and 2 (1\%) fully disagreed.

The graduates were asked if the course had prepared them to manage and administer both the workforce and physical and material resources and information. Twenty-eight graduates (16\%) fully agreed, 97 (56\%) agreed, 41 (24\%) disagreed and $2(1 \%)$ fully disagreed.

Participants were asked if the course had prepared them to manage the nursing work process in accordance with principles of Ethics and Bioethics. Of the responses, 51 (30\%) fully agreed, $102(59 \%)$ agreed, $17(10 \%)$ disagreed and $1(1 \%)$ fully disagreed.

They were asked if the course had prepared them to plan, implement and participate in the training and continuing qualification programs of nursing and health workers. Of the respondents, 28 (16\%) fully agreed, 104 (60\%) agreed, 36 (21\%) disagreed and 2 (1\%) fully disagreed.

Another question was whether the course had prepared them for education and health promotion, considering the specificity of different social groups and life, health, work and illness processes: forty graduates (23\%) fully agreed, 109 $(63 \%)$ agreed, 19 (1\%) disagreed and none fully disagreed.

When asked if the course had prepared them to integrate nursing with multi-professional practices: 32 (19\%) fully agreed, $96(56 \%)$ agreed, 39 (23\%) disagreed and 4 (2\%) fully disagreed.

Regarding continuing learning, training focused on responsibility and commitment to education: 75 (44\%) fully agreed, $83(48 \%)$ agreed, $10(6 \%)$ disagreed and none fully disagreed.

\section{DISCUSSION}

According to the characterization of the graduates, a predominance of females was observed, with a mean age of 29 years, most of them having finished their course before 2011. During graduation, the majority had devoted themselves exclusively to the course. Compared to the study of USP graduates from 2000 to $2005^{(4)}$, we observed that the students in the current study had a higher level of language skills, both in terms of proficiency and speaking more than one language.

The requirements for insertion in the labor market have increased, leading graduates to aspire mainly to specialization courses and residencies that focus on the qualification and improvement of technical skills. After graduation, the majority 
affirmed that they were able to practice their profession and find their first job within one year of completing the course.

The results show that hospitals still employ most of the nursing professionals, which is in accordance with the findings of a previous study with USP graduates ${ }^{(4)}$.

The second largest sector hiring the graduates in their first and third jobs was the Basic Health Unit (UBS) (14.6\% and $24 \%$, respectively); while in the second job most of the graduates worked in other institutions (21\%), such as management and research. These data corroborate the research findings with graduates of a university in Paraná(11). Against data from another study carried out with graduates from USP(4), it is possible to observe that there have been changes, previously; the second largest field of entry for graduates in their first and second jobs was the vocational training sector.

In the first, second and third jobs there were a greater insertion of graduates into the public sector $(55.5 \%, 53 \%$ and $53 \%$, respectively). The jobs were obtained mainly through the selection process, public tender and recommendations by colleagues. Likewise, a study carried out at the Federal University of Santa Catarina ${ }^{(8)}$ also showed that the main form of entry in the labor market occurred through the above means.

In relation to the time in each job, the vast majority of graduates reported an average of between six months and one year. This finding may be related to poor working conditions and remuneration that involve the Nursing profession as a whole ${ }^{(12)}$.

The minimum wage in force at the time of data collection was R\$ 788.00 (US\$257.51) and the commercial dollar was quoted on average at $\mathrm{R} \$ 3.06$. The second highest salary range in the first three jobs $(20.3 \%, 12.5 \%$, and $16.3 \%$ ) was US\$ 490.35 to 816.99 . In the first job, the monthly salary variation was from US\$ 196.07 to $2,287.58$, with the highest concentration of these graduates averaging US\$ 980.39 per month. In the second job, the salary variation was US\$ 254.90 to $3,267.97$ per month. Only $28 \%$ had a third job, with a salary variation of US\$ 653.59 to $2,385.62$ per month.

A study with USP nursing graduates ${ }^{(4)}$ showed that the salary ranged between US\$ 950.50 and 1,520.00 per month for their first, second and third year jobs (36\%, 28.5\% 16.5\%, respectively), followed by the range of US\$ 570.50 to 950.00 (26.8\%, $14.2 \%, 10.2 \%)$. The prevailing minimum wage at that time was about R\$380.00 (US\$ 190.00) and the commercial dollar was quoted on average at $\mathrm{R} \$ 2.00^{(4)}$. It should be underscored that the main activity performed by these graduates was in nursing care.

Regarding their employment situation at the time of data collection, the vast majority were already working in the labor market, with a high demand for nurses in the care $(66 \%)$, administrative (15\%) and educational (12\%) sectors. It is noted that the majority of graduates remained in the first and second jobs during the data collection period. The salary range with the highest concentration was between US\$ 980.55 and 1,633.98 (46\%), the highest average salary was offered by hospitals and this value was only surpassed by laboratories. The lowest average wage was found in the higher education sector, data in agreement with a previous survey conducted on USP graduates ${ }^{(4)}$.

With regard to the skills and competences requirements among nursing students, according to the NUCs, it was found that the course had fulfilled its commitment to train qualified, efficient and resolute professionals to work in the SUS from the perspective of promotion, prevention and rehabilitation and in view of the processes of health and disease produced socially and historically in human relations. From this point of view, the results of this study have enabled a broad insight into the current needs in the nurses' training process, as well as the necessary changes and impact on health care.

In this sense, the requirements highlighted in the nurses' training process are related to a growing variety of functions and attributions desirable for a leader who in his or her work process will guarantee quality care for the clients ${ }^{(13)}$.

Leadership is conceived as the ability to lead and organize group work toward goal achievement, considering effective communication and accurate decision making. In a study ${ }^{(14)}$ with college teachers on the training of nurses, leadership was identified as inherent in the work of nurses, and it is the responsibility of teachers to facilitate the development of this professional competence. For this, graduates should be stimulated from the undergraduate level to seek systematic and continuous improvement, in a critical, reflective and creative manner, while combining technical-scientific knowledge and personal skills.

Nurses, in their management process, also perform activities of quality and wastage control, forecasting and provision of materials, control of high-cost materials and guidance on appropriate use of materials. Therefore, it is necessary for the graduates to be able to administer the control and usage of materials, mediating the necessary contacts between the nursing and health team, for managing the stock levels and purchase of materials, as well as defining the most appropriate materials for the provision of care ${ }^{(15)}$.

In the nurses' work process, management of the team and care provided must be permeated by the principles of ethics and bioethics, as established in the Code of Ethics for nursing and in the NUCs. The great majority of participants in the present study agreed that the course had prepared them accordingly to meet these requirements. Other researchers ${ }^{(16)}$ carried out an analysis of the PPP of undergraduate Nursing courses from 16 federal universities in Brazil and found that $93.75 \%$ of the courses devoted at least one semester to studying this aspect. Another study ${ }^{(17)}$ has reported that ethical and bioethical consideration has proven to be essential for the training of nurses, given the demands for this professional to handle everyday conflicts, as well as in decision-making in the face of constant ethical dilemmas.

Authors $^{(16)}$ have emphasized that the teaching of ethics and bioethics during graduation is essential; however, there is a need for continuing education culture, reviewing and updating theoretical and practical aspects related to nursing. In this sense, the majority of graduates agreed that their course had prepared them for the process of continuing qualification. The process of continuing training and qualification tends to be successful when there is a possibility of intercession between college and service. From the exchange of knowledge and collaboration it is possible to reduce the distance between the academic world and that of the practical provision of health services, thereby achieving positive results ${ }^{(18)}$. 
A cross-sectional study ${ }^{(19)}$ carried out with 2,727 nursing workers in 10 Chinese hospitals has reported that $97.3 \%$ of the nurses participated in training and continuing qualification activities in the 12 months prior to the study. The main motivational factors were: desire to augment and update knowledge of new technologies and procedures, improve practical skills and global qualities, as well as maintain professional status and receive certification.

Regarding the process of health education for patient/user, family and community, there was a prevalence of the "agree" option, with emphasis on the need for articulation and establishing relationships. A study ${ }^{(1)}$ involving students and nursing professors showed that the participants believe that the college, together with the service and users, can construct the path ahead, through their relationships, dialogue, valuation of broad knowledge, humanization, health promotion, and an interdisciplinary and multidisciplinary approach, enabling the transformation of health programs and practices.

In this sense, the achievement of positive results also highlights articulated multi-professional work. The majority of students answered that they agreed that they had been prepared to integrate their activities into a multi-professional context. A study ${ }^{(20)}$ points out that the lack of multi-professional integration in health care leads to incomplete or even failed interventions. Multi-professional and interdisciplinary teamwork raises the quality standard and effective health outcomes. However, it is perceived that the lack of multi-professional integration is related to structural and historical aspects, mainly between the doctor and nurse. The colleges should invest in curricular restructuring that enables integrated teaching and promotes interdisciplinary training.

In addition to the interactive process, there is a need to prepare the student to learn continuously, to have responsibility and commitment to education, not only transmitting knowledge, but also providing conditions for the benefit of professionals working in the service, both currently and in the future. In relation to this question, the majority agreed that these aspects were covered during graduation.

The knowledge that will enable graduates to perform competently encompasses a series of activities shared with a professional community comprising teachers, researchers, practitioners and students, working together in the clinical practice $^{(21)}$. It is believed that one of the roles of the university is to foster possibilities, through teaching, research and extension, and in learning how to learn.

Qualitative research ${ }^{(21)}$ carried out at public universities in the State of São Paulo has shown that students understand the importance of perceiving themselves as an active subject in the construction of their own knowledge. Such that, it is not only necessary to demand the teaching they expect, but also to be motivated in the search for available resources and learning possibilities.

\section{Study limitations}

As a limitation of this research, it is important to note the difficulty in locating the graduates and returning the completed questionnaires, which was below our expectations.

\section{Contribution to the area of nursing, health or public policy}

The results of this study can also be extended to other national realities, guiding the training needs and requirements established for graduates in the labor market, since they point out the facilitating factors and difficulties of nurses seeking employment in the labor market of a major metropolis and by underscoring the skills and competencies required by nurses trained on the basis of the NUCs.

\section{CONCLUSION}

The research made it possible to trace the profile of nurses graduating from USP, to identify the influence of the training process on professional insertion in the labor market and to learn from the perspective of the graduates those skills and competences required in the world of work, according to the precepts of the NUCs. Among the latter, prevention, promotion, protection, rehabilitation, health management and multiprofessional actions are underscored.

The majority of graduates agreed that they were prepared to meet the health needs of the population, in view of the health and disease processes produced socially and historically in human relations. They affirmed that they were encouraged to seek systematic and continuous improvement, in a critical, reflective and creative manner, while combining technical-scientific knowledge and personal skills. Most of the graduates had found work in the labor market, mainly in hospitals and basic health units, these being the institutions that offer the highest average salaries, surpassed only by laboratories.

The most relevant facilitating factors for the insertion of graduates in the labor market were: academic training in the undergraduate course at USP; the university's reputation in the labor market; the knowledge acquired and seeking professional improvement; together with their posture and good performance in the selection processes. The greatest difficulties for insertion in the labor market were: requirement of postgraduate and or specialization in the area, lack of experience as a recent graduate and difficulties in the selection process.

The findings from the present study are important, because they encourage recently graduated nurses to consider the skills and competencies they should develop and or improve.

\section{REFERENCES}

1. Carbogim FC, Friedrich DBC, Soares TC, Castro EAB. Nursing education in Brazil: a look at holism in care. J Nurs Educ Pract[Internet]. 2013 [cited 2016 Feb 14];3(2):93-101. Available from: http://dx.doi.org/10.5430/jnep.v3n2p93

2. Silva KL, Sena RR, Tavares TS, Wan ML. [Expansion of undergraduate nursing and the labor market: reproducing inequalities]? Rev 
Bras Enferm[Internet]. 2012[cited 2016 Feb14];65(3):406-13. Available from: http://www.scielo.br/pdf/reben/v65n3/v65n3a03. pdf Portuguese

3. Carbogim FC, Friedrich DBC, Püschel VAA, Oliveira LB, Nascimento HR. Paradigma da integralidade no currículo e nas estratégias de ensino em enfermagem: um enfoque histórico-cultural. Rev Enferm Centro O Min [Internet]. 2014 [cited 2016 Jan 23];4(1):96170. Available from: http://www.seer.ufsj.edu.br/index.php/recom/article/view/426/571

4. Püschel VAA, Inacio MP, Pucci PPA. Insertion of USP nursing graduates into the job market: facilities and difficulties. Rev Esc Enferm USP [Internet]. 2009 [cited 2015 Jun 2015];43(3). Available from: http://www.revistas.usp.br/reeusp/article/view/40389/43346

5. Chrizostimo MM, Brandão AAP. The training professional of nurses: 'state of the art'. Enferm Global [Internet]. 2015 [cited 2016 Feb 12];40:430-45. Available from: http://revistas.um.es/eglobal/article/viewFile/208841/181721

6. Brasil. Ministério da Educação. Lei no 9.394, de 20 de dezembro de 1996. Estabelece as diretrizes e bases da educação nacional. Diário Oficial da União 23 dez 1996;34(248)Seção 1:27.833-41.

7. Brasil. Ministério da Educação. Conselho Nacional de Educação. Câmara da Educação Superior. Resolução n 3 , de 07 de novembro de 2001. Institui Diretrizes Curriculares Nacionais do Curso de Graduação em Enfermagem. Brasília(DF): Ministério da Educação e Cultura; 2001

8. Jesus BH, Gomes DC, Spillere LBB, Prado ML, Canever BP. [Job market placement: professional trajectory of nursing graduates]. Esc. Anna Nery Rev Enferm[Internet]. 2013 [cited 2016 Feb 14];17(2):336-45. Available from: http://www.scielo.br/pdf/ean/ v17n2/v17n2a19.pdf Portuguese

9. Oliveira MAC, Veríssimo MDLOR, Püschel VAA, Riesco MLG. Challenges in nursing education in Brazil: baccalaureate curricular proposal of the School of Nursing of Sao Paulo University. Rev Esc Enferm USP [Internet]. 2007[cited 2016 Feb 14];41(spe):820-5. Available from: https://www.ncbi.nlm.nih.gov/pubmed/20608384

10. Universidade de São Paulo. Escola de Enfermagem da Universidade de São Paulo. Projeto Político Pedagógico do Bacharelado em Enfermagem. São Paulo: Universidade de São Paulo, 2011 [cited 2016 Feb 14]. Available from: http://www.ee.usp.br/ensino/ graduacao/Projeto $\% 20$ Politico $\% 20$ Pedag $\%$ C3\%B3gico/Projeto_Politico_Pedagogico_do_Curso_de_Bacharelado_em_Enfermagem. PDF

11. Colenci R, Berti HW. Professional development and entering the labor market: the perceptions of nursing graduates. Rev Esc Enferm USP [Internet]. 2012 [cited 2016 Feb 14];46(1):158-66. Available from: http://www.scielo.br/pdf/reeusp/v46n1/en_v46n1a22.pdf

12. Griep RH, Fonseca MJM, Melo ECP, Portela LF, Rotenberg L. [Nurses of large public hospitals in Rio de Janeiro: socio demographic and work related characteristics]. Rev Bras Enferm[Internet]. 2013[cited 2016 Feb 14];66(spe):151-7. Available from: http://www. scielo.br/pdf/reben/v66nspe/v66nspea19.pdf Portuguese

13. Meira MDD, Kurcgant P. Nursing education: training evaluation by graduates, employers and teachers. Rev Bras Enferm [Internet]. 2016[cited 2016 Feb 14];69(1):16-22. Available from: http://www.scielo.br/pdf/reben/v69n1/en_0034-7167-reben-69-01-0016.pdf

14. Avila VC, Amestoy SC, Porto AR, Thofehrn MB, Trindade LL, Figueira AB. [The view of nursing students on the training of nurseleaders]. Cogitare Enferm[Internet]. 2012[cited 2016 Feb 14];17(4):621-7. Available from: http://ojs.c3sl.ufpr.br/ojs/index.php/ cogitare/article/download/30357/19635 $+\& \mathrm{~cd}=1 \& \mathrm{hl}=\mathrm{pt}-\mathrm{BR} \& \mathrm{ct}=\mathrm{clnk} \& \mathrm{gl}=$ br Portuguese

15. Camelo SHH. Professional competences of nurse to work in Intensive Care Units: an integrative review. Rev Latino-Am Enfermagem[Internet]. 2012 [cited 2016 Feb 14];20(1):192-200. Available from: http://www.scielo.br/pdf/rlae/v20n1/25.pdf

16. Couto FJCF, Souza FS, Silva SS, Yarid S, Sena ELS. Survey of bioethics teaching in Nursing Courses of Brazilian Federal Universities. Rev Bioét[Internet]. 2013[cited 2016 Feb 14];21(1):179-85. Available from: http://www.scielo.br/pdf/bioet/v21n1/a21v21n1.pdf

17. Mascarenhas NB, Santa RDO. The teaching of Bioethics in the education of nurses: interface with the adopted literature. Acta Paul Enferm[Internet]. 2010[cited 2016 Feb 14];23(3):392-8. Available from: http://www.scielo.br/pdf/ape/v23n3/en_v23n3a13.pdf

18. Duarte MLC, Ferreira AM, Torres OM, Moreira CM, Bulhosa M. Work-Based Learning Program: an experience report on workers' training. Cogitare Enferm[Internet] 2014 [cited 2016 Feb 14];19(1):168-71. Available from: http://dx.doi. org/10.5380/ce.v19i1.35976

19. Ni C, Hua Y, Pei S, Gwenyth RW, Shasha X, Lu L. Continuing education among Chinese nurses: a general hospital-based study. Nurse Educ Today[Internet] 2014 [cited 2016 Feb 14];34(4):592-7. Available from: http://www.sciencedirect.com/science/article/ pii/S0260691713002645

20. Adhikari R, Tocher J, Smith P, Corcoran J, MacArthur J. A multi-disciplinary approach to medication safety and the implication for nursing education and practice. Nurse Educ Today. [Internet] 2014 [cited 2016 Feb 14];34(2):185-90. Available from: http://www. nurseeducationtoday.com/article/S0260-6917(13)00384-5/pdf

21. Merighi MAB, Jesus MCP, Domingos SRF, Oliveira DM, Ito TN. Teaching and learning in the clinical field: perspective of teachers, nurses and nursing students. Rev Bras Enferm[Internet]. 2014[cited 2016 Feb 14];67(4):505-11. Available from: http://www.scielo. br/pdf/reben/v67n4/0034-7167-reben-67-04-0505.pdf 